\title{
Impact of Microfinance on Socioeconomic Status of Farmers in District Dera Ismail Khan
}

\author{
Muhammad Naveed Anjum ${ }^{1}$, Abdur Rehman ${ }^{1 *}$, Muhammad Niamatullah Khan ${ }^{1}$, Raheel Saqib ${ }^{2}$, \\ Mohammad Fayaz ${ }^{3}$ and Iqbal Javed ${ }^{4}$
}

${ }^{1}$ Institute of Social sciences, Department of Agricultural Economics, Faculty of Agriculture, Gomal University, Dera Ismail Khan, Khyber Pakbtunkhwa, Pakistan; ${ }^{2}$ Department of Agricultural Extension, Education and Communication, The University of Agriculture Peshawar, Khyber Pakhtunkhwa, Pakistan; ${ }^{3}$ Department of Agriculture and Applied Economics, The University of Agriculture Peshawar, Khyber Pakhtunkhwa, Pakistan; ${ }^{4}$ Department of Economics, The University of Lahore, Sargodha Campus, Sargodha, Pakistan

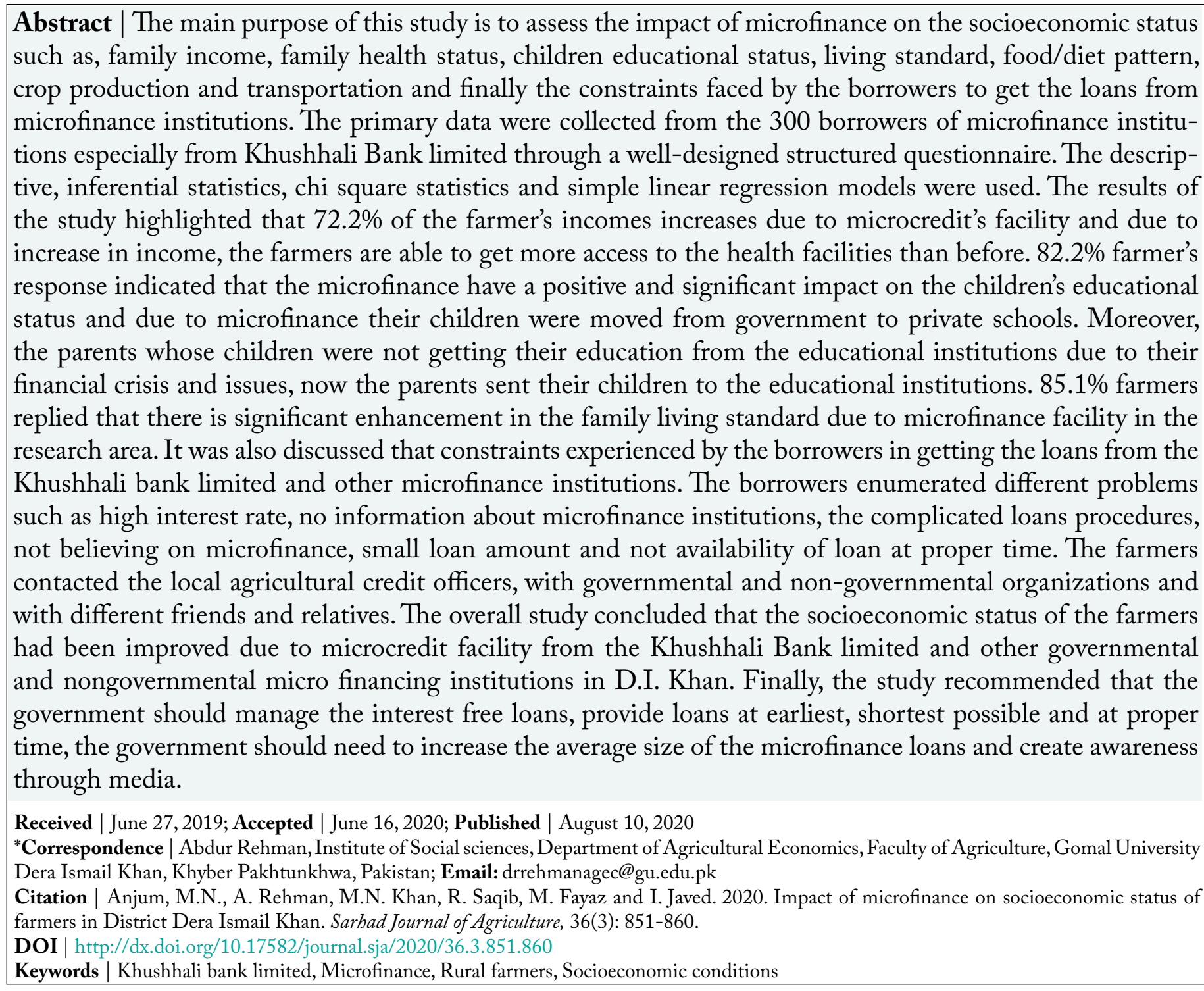

September 2020 | Volume 36 | Issue 3 | Page 851 
Introduction

$\mathrm{T}$ he origin of microfinance is not possible to explain in all over the world. The Americans for Community Cooperation in Other Nations (ACCION) was started in 1961 with the initial investment of 90,000 dollars in South America. At first the main aim of the company was to build educational institutes and drinking water schemes, later on in 1973 it was turned into microfinance institution. In Columbia and Indonesia, AI Whittaker and David Bussau used to give loans to small business persons in 1971. The beginning of recent microfinance traced back to the 1976, Muhammad Younus observed a poverty situation in rural areas of Bangladesh and how it is alleviated by providing small credit facilities to the poor people of the countryside. Micro financing is more absorbed to poverty reduction as compared to increase in microenterprise. First time he was awarded the Nobel Peace Prize for introducing the microfinance.

According to the 2005 survey executed by the World Bank about fourteen million dynamic borrowers are served by the Non-Governmental OrganizationMicrofinance Institutions. In Pakistan, micro financial assistance is mainly provided through Micro Finance Institutions (MFIs), Micro Finance Banks, Rural Support Programs and Benazir Income Support Program (BISP), they provide credit services to the poor people. Micro Finance Institutions (MFIs) are providing financial and economic assistance to the poor community and borrowers to get good employment opportunities to overcome their social-economic problems and more income generating businesses. These organizations are mostly associated with informal commercial banking and Non-Governmental Organizations (NGOs) and not essentially allied with Government institutions. Admittance and access to the community of the countryside, monetary and financial services has a potential to make a distinction in agricultural farm productivity and poverty mitigation. Development is not possible without enhancement of farming sector. However, a well-organized, sustainable and extensively reachable to countryside monetary and economic system remains as an uncertain block as a foremost developmental challenges in mainly of the developing countries.

Microfinance is the great opportunity for the people of developing countries like India, Bangladesh and Pakistan. It is the successful step for the farmers to begin their own business and generating the income. It plays an important role to generate the self-employment opportunities through business and other economic activities. Microfinance has a lot of results providing to farmer communities such as creating business opportunities, increasing incomes, developing family education and women's wellbeing, however microfinance could be the good responsibilities to the community. The group of deprived and poor people who were the beneficiaries of the micro credit facility to change their living standards. After using these financial resources people feel comfortable than before. Augmentation and enhancement of Agriculture sector is necessary part for the improvement and development of the countryside and especially for the improvement of socioeconomic conditions of the community. This sector more relies on credit availability than any other sectors due to uncertain seasonal/climatic changes in the growers' yield or profits and a changeable inclination from sustenance to farming business. Agricultural microcredit provides monetary and economic assistance to the farmers to buy agriculture inputs like seeds, insecticides, fertilizers, farm machinery and equipment's etc. Pakistan is providing financial resources to poor farmers for improving the socio economic conditions. Pakistan is developing country and most of the people facing financial problems. Microfinance is defined as extending of grants or financial aid such as small loans, savings and payment services to people for improving their socioeconomic condition and establishing their businesses. Therefore, farmers need monetary and financial assistance to improve their social and economic status.

The opinions and suggestions of different scholars about the impact of microfinance on the socioeconomic conditions of rural farmers are as under. Oltiana et al. (2018) studied the influence of microfinance was improving and enhancing the existing conditions of rural peoples in the region of Vlore and Fier, Albania. The study defined that microfinance was the providing of monetary services to the people, while access to micro-credit has realized as a right to have credit, it fairly shows the growth and financial enterprises that should change the people's living standard. Choudhry et al. (2017) assessed the success of microcredits on income level, expenses and investments by examining 
farmers who had successfully taken loan at least three times. The necessary information's were collected from almost 300 farmers by survey method, which were receiving the credits from different financial institutes and other non-government organization. The result of multiple regression models clearly shows that the microcredit program had significant influence on income level of the respondents, expenses and investments. Furthermore, microcredits program played a key role to reduce poverty and enhancing the living standard of rural and urban farmers which were taken loans from microcredits scheme, especially ASA in Bangladesh. Murad (2017) studied the impact of microfinance institutions on economic growth of a country by using the multiple regression analysis in Nigeria. The secondary data from 19922012 of all commercial banks were extracted from the Central Bank of Nigeria statistical Bulletin and Annual Reports. The results of the study indicate that microfinance have a significant positive impact on the short run economic performance by increasing the consumption per capita in Nigeria, while these banks loans do not have a significant impact on economic growth in the long run. This study also focused to boost the agricultural production and per capita income in Nigeria. Weerasinghe and Dedun (2017) studied the impact of micro credits on the poor community of Kurunegala District of Sri Lanka. There are three main micro institute i.e. micro credit, Advisory services and Micro saving. The data of 152 respondents were collected randomly and analyzed through SPSS package. They concluded that microfinance has significant linkage between micro credits, advisory support; saving and living standard of people of district Kurunegala.

The study recommended that the microfinance institutions provided attractive option to raise the standard of living of poor communities. Advisory support provided management of loan, start business, prepare business plan, identify customer requirement through continuous training program. Hassan (2017) studied the impact of microfinance on the socioeconomic conditions of poor's in Pakistan. Akhuwat Foundation is the microfinance institute in Pakistan which is providing the credits on interest free to promoting the poorest communities of the country. It was launched in 2001 and now make an interest free (Qarze e Hasna) institution in the world and analyzed the impact of old loaners was much higher than new loaners. Mehar-ul-Nisa (2016) studied the status of borrowers of district Dado and effect of microcredits on the income of the farmers. There were 60 farmers in which 20 farmers of sugarcane, 20 farmers of wheat and 20 farmers of rice were selected. There were almost farmers getting loan from Thardeep (A nongovernment organization) but some were getting from Khushali Bank and other Microfinance Banks. Out of these farmer's majority (84\%) farmers were using the loan for business purposes and $1 / 4$ of the farmers were using for family needs. The result indicated that by using the microfinance, the famers who were growing sugarcane were getting the maximum earning as compare to growers of wheat and rice. Tahir et al. (2016) analyzed the contribution of microfinance to enhance the living standard of rural household and reduce the poverty in Layyah and D.G. Khan districts. Statistical and econometric techniques were used to explore the impact of the microfinance. The results indicated that the poor household's income and consumption were significantly affected by microcredits and the provision of microcredits leads to increase in productive activities as compared to consumption. Iqbal et al. (2015) observed that most of the farmers were no access to gain the micro credits, particularly in Sub-Saharan Africa.

The study mainly focused on the prosperity of small scale farmers through micro financing in Nyamagabe District, Rwanda. The descriptive statistics and Probit Model were used and finally observed that $48 \%$ of household using the microfinance where as $52 \%$ of household not involved in microfinance services and concluded that microfinance services can be used to increase the living standard of small scale farmers in the study area. The results showed that $90 \%$ of the farmers earn from agriculture by using the micro credits. And the high interest rate was negative effect on the farmers. Finally, this study concluded that interest rate should be decreased and there should be a good relation between farmers and microfinance banks. The farmers should be literate to manage and expand their income. Ahmad (2014) studied the impacts of micro-finance on socioeconomic status of farmers in Bosan and Sher Shah villages of Multan city. Quantitative sample were collected and the sample consisted of all borrowers of ZTBL. About 120 respondents were interviewed through questionnaires and analyzed. The result indicated that access to microfinance has improved the production of crops and raising the living standards of the peoples. The researchers evaluated that micro credits 
should be given at proper time because it has caused the minimum profit. Nouman et al. (2013) stated the effect of microfinance on socio economic status in district Swabi and the data were collected from 80 sampled farmers through well designed structural questionnaire. Credits was used as a dependent variable while socioeconomic characteristics such as age, marital status, income, farm size, farm experience were used as an independent variable. Logit Model has been utilized for the purpose of data analysis. The study suggests that micro credits affect the socioeconomic status of farmers in district Swabi. Dipak and Jayanti (2013) evaluated the concept of microcredit to move small investment of rural farmers to generate credit, available in time and on easy access, especially women. Results concluded that microcredits were an operational means for getting helpful effect on the financial position of the peoples beside their household and facilitated to produce additional income for their household. The further income lets the respondent to purchase healthy diet, contact to recent health care centers, furthermore and also able to send their children in schools and colleges. The main objective of the research study is to evaluate the impact of microfinance on the socio-economic status of rural farmers and the problems faced by the borrowers to get the loans from the microfinance institutions.

\section{Hypothesis of the study}

$\mathbf{H}_{\mathbf{0}}$ : There is no impact of financial assistance on the socioeconomic conditions of the farmers in district Dera Ismail Khan.

$\mathbf{H}_{\mathbf{1}}$ : There is impact of financial assistance on the socioeconomic conditions of the farmers in district Dera Ismail Khan

\section{Materials and Methods}

\section{Parameter of the study}

The following parameters were studied i.e. family income, family health status, children educational status, living standard, food/diet pattern, crop production and transportation.

\section{The data collection techniques}

The current study was included; both the primary and secondary data composed by the researcher through well designed and structured questionnaire from micro finance institutions especially from Khushhali Bank Limited and group discussions with different micro finance officers and managers in district D.I. Khan. The majority of the farmers of district D.I. Khan living in rural areas takes loans from KBL etc. The researcher was collected a list of farmers from KBL etc. of district D.I. Khan. A total of 300 respondents were randomly selected from KBL etc. borrowers on equal basis.

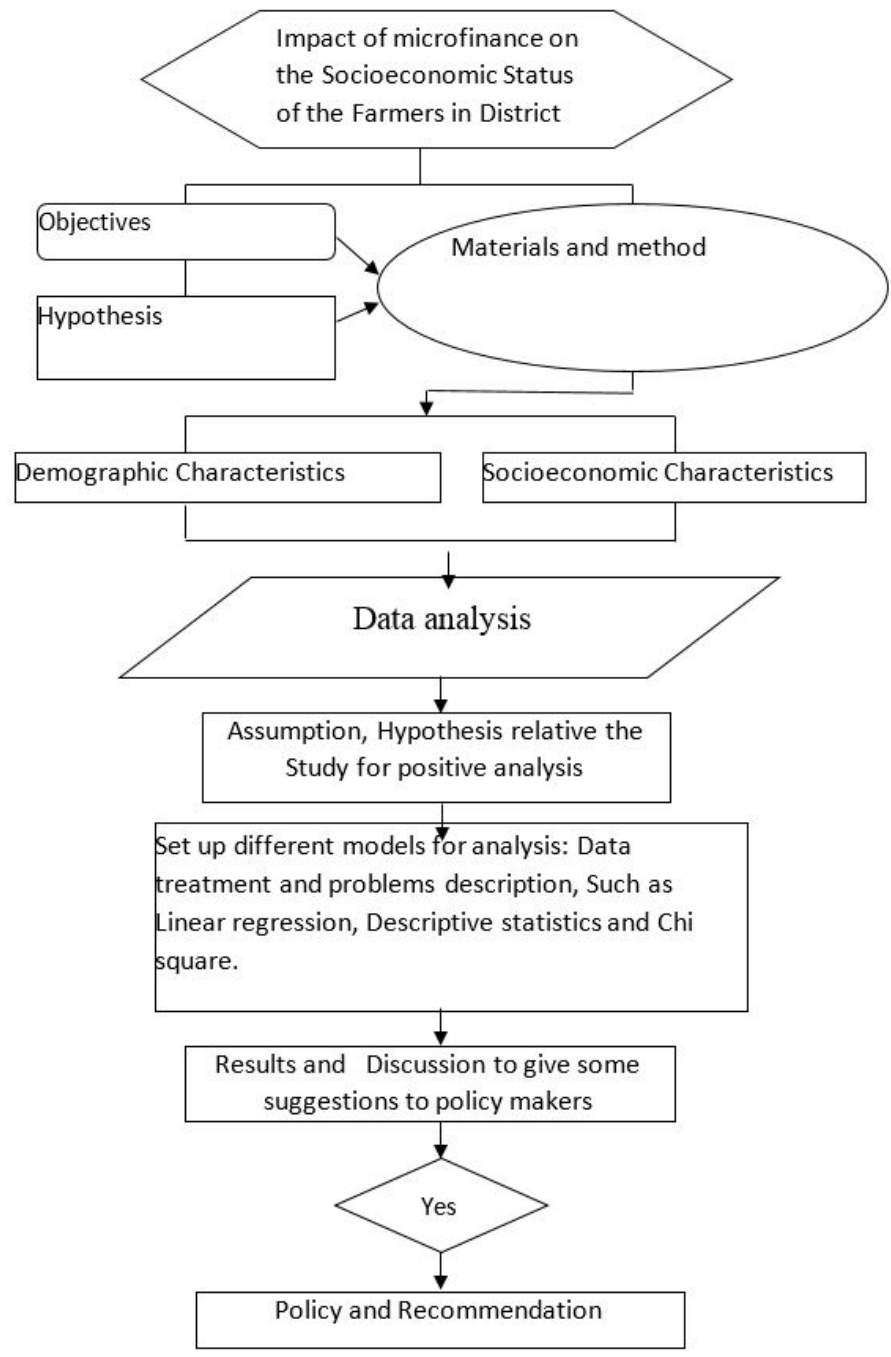

Figure 1: Technical route of the study.

\section{Analysis techniques}

The given Data were studied by using the software of Statistical Package for Social Sciences (SPSS, version 16.0). Simple Linear regression model, Descriptive, inferential statistics and Chi Square test were used to get the results.

\section{Results and Discussion}

Socioeconomic characteristics of microfinance borrowers in District D.I. Khan

Income increased by microfinance facility: The impact of microfinance on the income of farmers depicted from Table 1, that majority (72.2\%) farmers 
replied that their income enhanced due to micro credits facilities. While (16.9\%) farmers replied that their income were not increased. Moreover (10.9\%) farmers replied that there was no effect on their income. The result is consistent with the results of Choudhry et al. (2017), Faith and Kevin (2017) and Murad (2017).

Table 1: Income increased by microcredit facility.

$\begin{array}{lll}\text { Income increased } & \text { Number of respondents } & \text { Percentage (\%) } \\ \text { Yes } & 218 & 72.2 \\ \text { No } & 51 & 16.9 \\ \text { No effect } & 31 & 10.9 \\ \text { Total } & 300 & 100\end{array}$

Source: Survey data 2017-18.

\section{Improvement in health status}

Table 2 indicates that $87.3 \%$ farmers replied that their health status improved due to their improved income status by the expansion of the increase in their yield. And so they become capable to use additional money to preserve the health status and develop entrance to the health status. Due to development in health it can be supposed that the credit sum showed useful for the farmers in numerous means to encourage their socioeconomic status and to complete the requirement of their health expenses to preserve and get better their health, while a very small number $7.2 \%$ of farmers said that there is no change in their health status, only $3.9 \%$ respondents said that there is no effect on our health status. And the result is consistent with the results of Dipak and Jayanti (2013) and Urvashi and Vinita (2017).

Table 2: Improvement and development in health status.

$\begin{array}{lll}\begin{array}{l}\text { Improvement in } \\ \text { health status }\end{array} & \text { No. of respondents } & \text { Percentage (\%) } \\ \text { Yes } & 266 & 87.3 \\ \text { No } & 22 & 7.2 \\ \text { No effect } & 12 & 3.9 \\ \text { Total } & 300 & 100\end{array}$

Source: Survey data 2017-18

\section{Improvement in children's education}

Table 3 depicts that $82.8 \%$ respondents said that their children's educational status improved in line for rise in their earnings, while $14.9 \%$ farmers replied that there has no improvement in their children's education. On the basis of monetary incomes, they use further money on their children's education. Getting the economic resources, they are capable to teach their children rather than linking them in labor and other activities. Enhancement of income made them able to helpful to achieve the learning expenses of their children. Therefore, it is clearly said that micro credits schemes play a vital role to uplifting their educational condition indicating rewarding welfares. And the result is consistent with the results of Sivchou et al. (2012), Perceval et al. (2017) and Viswanath (2018).

Table 3: Improvement and development in children education.

$\begin{array}{lll}\begin{array}{l}\text { Improvement in chil- } \\ \text { dren education }\end{array} & \begin{array}{l}\text { Number of respond- } \\ \text { ents }\end{array} & \begin{array}{l}\text { Percentage } \\ \text { (\%) }\end{array} \\ \text { Yes } & 250 & 82.8 \\ \text { No } & 43 & 14.9 \\ \text { No effect } & 7 & 2.3 \\ \text { Total } & 300 & 100\end{array}$

Source: Survey data 2017-18

\section{Improvement in housebold living standard of the respondents}

Table 4 depicts that due to increase in income, which is the major source to improve the family living standard and upholding the domestic expenses, which also further indicates that most of the farmers $85.1 \%$ have improved the living standard of their household due to the microcredit facility. Microcredits drastically increased the earnings of the respondents and due to increase in their income they get superior economic status. Achievement in living standard of the respondents can definitely accomplish the basic necessities of livelihood and maintain family expenses. Thus, their standard of living and entrance to the important facilities of the household have also been upgraded. And the result consistent with the results of Urvashi and Vinita (2017).

\section{Table 4: Improvement in household living standard of the respondents.}

$\begin{array}{lll}\begin{array}{l}\text { Household living standard of the } \\ \text { respondents respondents }\end{array} & \begin{array}{l}\text { Number of } \\ \text { respondents }\end{array} & \begin{array}{l}\text { Percent- } \\ \text { age (\%) }\end{array} \\ \text { Yes } & 257 & 85.1 \\ \text { No } & 31 & 10.9 \\ \text { No effect } & 12 & 4.0 \\ \text { Total } & 302 & 100\end{array}$

Source: Survey data 2017-18.

\section{Improvement in farmers food/diet pattern}

Table 5 shows the considerable enhancement in the food or diet patterns. Mostly 51.3\% of the 
respondent's diet is better due to rise in the level of income and getting of improved family living standards. It depicts the advantages of the credits which successfully increased the food arrangements of the farmers by enhancing their farming output with monetary support. A better economic status made them to create opportunities for healthier diets arrangement. The result consistent with the results of Adhikari and Shrestha (2013).

Table 5: Improvement in farmers food/diet pattern.

$\begin{array}{lll}\begin{array}{l}\text { Improvement in farmers Food/ } \\ \text { Diet pattern }\end{array} & \begin{array}{l}\text { Number of } \\ \text { respondents }\end{array} & \begin{array}{l}\text { Percentage } \\ \text { (\%) }\end{array} \\ \text { Yes } & 151 & 51.3 \\ \text { No } & 106 & 34.3 \\ \text { No effect } & 43 & 14.3 \\ \text { Total } & 302 & 100\end{array}$

Source: Survey data 2017-18.

\section{Impact of microfinance on crop production}

The Table 6 shows that $84.1 \%$ of the respondents having great extent effect of loan on crop production, moreover $11.7 \%$ of the farmers having some extent effect of credits on crop production and $2.3 \%$ of the farmers haven't impact on crop production. The result consistent with the results of Aminu and Samuel (2015).

Table 6: Impact of microfinance on crop production.

$\begin{array}{lll}\text { Crop production } & \text { Number of respondents } & \text { Percentage } \\ \text { Greater extant } & 257 & 84.1 \\ \text { Some extant } & 36 & 11.7 \\ \text { No effect } & 7 & 2.3 \\ \text { Total } & 300 & 100\end{array}$

Source: Survey data 2017-18.

\section{Impact of microfinance on transportation}

Transport is definitely a main concern of farming communities for contact to the marketplace. Microcredits institutions offer farmers to purchase their personal means of transport. $48.7 \%$ of the farmers having to great effect of loan on their conveyance as they purchase vehicles and other agricultural machinery to carriage their crops for to get access market, while $29.1 \%$ of the respondents having some extant effect of loan on their transportation and $21.2 \%$ of the respondents having no effect on their transportation. The result is similar to that of Haque et al. (2011).
Table 7: Impact of microfinance on transportation.

$\begin{array}{lll}\text { Crop production } & \text { Number of respondents } & \text { Percentage } \\ \text { Greater extant } & 150 & 48.7 \\ \text { Some extant } & 88 & 29.1 \\ \text { No effect } & 64 & 21.2 \\ \text { Total } & 300 & 100\end{array}$

Source: Survey data 2017-18.

Case 1: Model for Income increased due to microcredit facility

$$
Y=a+a_{1} X_{1}+\mu
$$

Where;

$\mathrm{Y}=$ Income increased due to microcredit facility; $\mathrm{a}=$ Intercept; a1= coefficient; X1= Level of Microfinance (Sig Value is 0.000 ); $\mu=$ Error Term.

\section{Table 8: Impact of microfinance on income.}

\begin{tabular}{|c|c|c|c|c|c|}
\hline \multirow[t]{2}{*}{ Model } & \multicolumn{2}{|c|}{$\begin{array}{l}\text { Unstandardized } \\
\text { coefficients }\end{array}$} & \multirow{2}{*}{$\begin{array}{l}\text { Standardized } \\
\text { coefficients } \\
\text { Beta }\end{array}$} & \multirow[t]{2}{*}{$\mathbf{T}$} & \multirow[t]{2}{*}{ Sig. } \\
\hline & B & Std. error & & & \\
\hline (Constant) & .140 & .040 & & 3.474 & .000 \\
\hline $\begin{array}{l}\text { Level of } \mathrm{Mi}^{-} \\
\text {crofinance }\end{array}$ & .852 & .025 & .893 & 34.321 & .000 \\
\hline
\end{tabular}

Source: Author's calculation.

Table 8 depicts the impact of microfinance on the income level of the farmers, which shows that there is positive and significant impact of microfinance on the income of the farmers at $(\mathrm{P}<0.01)$ in District Dera Ismail Khan. The result of the current study consistent with the results of previous research steered by Razaulhind (2014), which concluded that microcredit has positive impact on the income of the farmers.

Case 2: Model in improvement of health status of the farmers due to microfinance

$$
Y=a+a_{1} X_{1}+\mu
$$

Where;

$Y=I m p r o v e m e n t$ in Health Status of Farmer; $a=$ Intercept; $\mathrm{a} 1=$ Coefficient; X1 = Level of Microfinance (Sig value is 0.038 ); $\mu=$ Error Term.

Table 9 shows the significant and positive impact of microfinance on the level of the health Status of the farmers in the rural areas of District D.I. Khan at 
$\mathrm{P}<0.05$. The current study is associated with previous study by Ahmad (2014) stated that microfinance provides farmers to access basic health services which they do not have before getting microfinance. Hence it is concluded that health is constantly matter for peoples and is the main apprehension for the government and they prepared health hubs frequently in all study areas to offer better health facilities.

Table 9: Improvement in health status of the farmers.

\begin{tabular}{|c|c|c|c|c|c|}
\hline \multirow[t]{2}{*}{ Model 1} & \multicolumn{2}{|c|}{$\begin{array}{l}\text { Unstandardized } \\
\text { coefficients }\end{array}$} & \multirow{2}{*}{$\begin{array}{l}\text { Standardized } \\
\text { coefficients } \\
\text { Beta }\end{array}$} & \multirow[t]{2}{*}{$\mathbf{T}$} & \multirow[t]{2}{*}{ Sig. } \\
\hline & B & Std. error & & & \\
\hline (Constant) & 1.039 & .060 & & 17.274 & .000 \\
\hline $\begin{array}{l}\text { Level of } \mathrm{Mi}^{-} \\
\text {crofinance }\end{array}$ & .077 & .037 & .120 & 2.088 & .038 \\
\hline
\end{tabular}

Source: Author's calculation.

Case 3: Model for improvement in children's education

Where

$$
Y=a+a_{1} X_{1}+\mu
$$

$\mathrm{Y}=$ Improvement in Children's Education; $\mathrm{a}=$ Intercept; $\mathrm{a}_{1}=$ Coefficient; $\mathrm{X}_{1}=$ Level of Microfinance (Sig value is 0.000 ); $\mu=$ Error Term.

Table 10: Impact of microfinance on children's education.

\begin{tabular}{lllllll} 
Model & \multicolumn{2}{l}{$\begin{array}{l}\text { Unstandardized } \\
\text { coefficients }\end{array}$} & $\begin{array}{l}\text { Standardized } \\
\text { coefficients }\end{array}$ & T & Sig. \\
& B & Std. error & Beta & & \\
(Constant) & .223 & .033 & & 6.676 & .000 \\
$\begin{array}{l}\text { Level of } \\
\text { Microfinance }\end{array}$ & .791 & .025 & .875 & 31.336 & .000 \\
\end{tabular}

Source: Author's calculation.

Table 10 indicates the significant and positive impact of microfinance on the improvement of children's education in District Dera Ismail Khan. The present study is compared with previous studies conducted by Razaulhind (2014) elaborated that microfinance provides monetary capitals after improvement in production; they use more credits on the children educations. Success of monetary assets made them able to educate their children rather than involving them in labor and other farm duties. Increased income has been very supportive for them to fulfill the educational expenditures of their children. Therefore, the findings are clearly indicating towards productive benefits of the microcredit institutes for the respondents in moving their educational status to access the basic need of good education.
Case 4: Model for improvement in housebold living standard of the respondents

Where

$$
Y=a+a_{1} X_{1}+\mu
$$

$\mathrm{Y}=$ Improvement in living standard of the respondents; $\mathrm{a}=$ Intercept; $\mathrm{a}_{1}=$ coefficient; $\mathrm{X}_{1}=$ Level of Microfinance (Sig value is 0.000 ); $\mu=$ Error Term

Table 11: Impact of microfinance on living standard of

\begin{tabular}{|c|c|c|c|c|c|}
\hline \multirow[t]{2}{*}{ Model } & \multicolumn{2}{|c|}{$\begin{array}{l}\text { Unstandardized } \\
\text { coefficients }\end{array}$} & \multirow{2}{*}{$\begin{array}{l}\text { Standardized } \\
\text { coefficients } \\
\text { Beta }\end{array}$} & \multirow{2}{*}{$\mathbf{T}$} & \multirow[t]{2}{*}{ Sig. } \\
\hline & B & Std. error & & & \\
\hline (Constant) & .202 & .035 & & 5.842 & .000 \\
\hline $\begin{array}{l}\text { Level of } \mathrm{Mi}^{-} \\
\text {crofinance }\end{array}$ & .808 & .026 & .874 & 31.091 & .000 \\
\hline
\end{tabular}
farmers.

Source: Author's calculation.

Table 11 depicts the significant and positive impact of microfinance on the living standard of the farmers $(\mathrm{P}<0.01)$ in the area of District D.I. Khan. The present study is compared with forgoing studies accompanied by Tahir et al. (2016) elaborated that microcredits has a significant impact in improving the living standard of unindustrialized nations, i.e. Pakistan. This study observes the involvement of microcredits in two less industrialized areas of D.G. Khan and Layyah with esteem to its influence on living standard. He observes that microcredits have expressively improved the income of deprived family and upraised their living standard.

Case 5: Model for improvement in farmers food/diet patterns

$$
Y=a+a_{1} X_{1}+\mu
$$

\section{Where}

$\mathrm{Y}=$ Improvement in Farmers Food/Diet Patterns; $\mathrm{a}=$ Intercept; $\mathrm{a}_{1}=$ Coefficient; X1=Level of Microfinance (Sig value is 0.000 ); $\mu=$ Error Term.

Table 12 indicates the significant and positive impact of microfinance on the farmers Food/Diet Patterns $(\mathrm{P}<0.05)$ in the study area. The current study is in linked with preceding study shown by Razaulhind (2014) observed that microcredit which successfully enhanced the food arrangements of the farmers done to enhance their farming output. A better monetary situation prepared to healthier diets for yourself and for household. 
Table 12: Impact of microfinance on the farmers food diet pattern.

\begin{tabular}{|c|c|c|c|c|c|}
\hline \multirow[t]{2}{*}{ Model } & \multicolumn{2}{|c|}{$\begin{array}{l}\text { Unstandardized } \\
\text { coefficients }\end{array}$} & \multirow{2}{*}{$\begin{array}{l}\text { Standardized } \\
\text { coefficients } \\
\text { Beta }\end{array}$} & \multirow[t]{2}{*}{$\mathrm{T}$} & \multirow[t]{2}{*}{ Sig. } \\
\hline & B & Std. error & & & \\
\hline (Constant) & .170 & .049 & & 3.487 & .000 \\
\hline $\begin{array}{l}\text { Level of Mi- } \\
\text { crofinance }\end{array}$ & .876 & .027 & .884 & 32.693 & .000 \\
\hline
\end{tabular}

Source: Author's calculation.

\section{Chisquare}

In the current study the Chi square test is used to prove the relationship between the microfinance and the socioeconomic conditions of the farmers, where microfinance as an independent variable while income, health, education, living standard and food was used as dependent variables. The hypothesis of the current research was that there is no impact of financial assistance on the socioeconomic status of the farmers in district D.I. Khan, while that there is no impact of financial assistance on the socioeconomic status of the farmers in district D.I. Khan. This was useful to examine the identified assumptions. For testing the connection between the two variables, significance level considered as $\alpha=0.05$. Relationship between Microfinance and enhancement in the socioeconomic condition of the farmers. $\mathrm{df}$ value $=(2$-sided $)$

Table 13: Chi square test.

$\begin{array}{llll} & \text { Value } & \text { Df Asymp. Sig. (2-sided) } \\ \text { Pearson Chi-square } & 14.148 & 4 & .007 \\ \text { Likelihood ratio } & 12.079 & 4 & .017 \\ \text { Linear-by-linear association } & 5.249 & 1 & .022 \\ \text { N of valid cases } & 300 & & \\ \text { Source: Author's calculation. } & & \end{array}$

Table 13 indicates that there is relationship among the variables. Chi-square value $=14.148$, d. $f=4$ and the level of significance is less than 0.05 . Therefore, the alternative hypothesis was assumed here as the impact of financial assistance on the socioeconomic status of the farmers in district D.I. Khan is established and insignificant. And there is no impact of financial assistance on the socioeconomic status of the respondents in district D.I. Khan, which is rejected.

\section{Issues experienced by the borrowers}

During the survey 2017-18, when the investigator of the research study, contacted the 300 borrowers of different microfinance institutions specially Khushhali
Bank limited, whether they get loan again from these microfinance institutions or not. They discussed their different problems about not getting the loans. Majority $27.4 \%$ of the respondents complained that interest rate is high, while $23.1 \%$ respondents said that we don't know about microfinance institutes, $24.8 \%$ respondents said that loan procedure is too complicated and we cannot fill the requirements, $6.5 \%$ respondents said that we don't believe on microfinance while $11.4 \%$ respondents said that we don't access to the micro finance institutes, $2 \%$ respondents said that loan amount is very small while $0.7 \%$ respondents said that Don't believe on group personal guarantee loan and only $1 \%$ respondents said that loan is not available at proper time and $1.6 \%$ discussed the other problems.

Table 14: Issue experienced by the borrowers of microfinance institutions.

$\begin{array}{lll}\text { Issues } & \begin{array}{l}\text { Number of } \\ \text { respondents }\end{array} & \begin{array}{l}\text { Percent- } \\ \text { age (\%) }\end{array} \\ \text { Interest rate is high } & 82 & 27.4 \\ \text { Don't know about microfinance institutes } & 71 & 23.1 \\ \text { Loan procedure is too complicated } & 76 & 24.8 \\ \text { Don't believe on microfinance } & 20 & 6.5 \\ \text { Don't access to the microfinance institutes } & 35 & 11.4 \\ \text { Loan amount is very small } & 6 & 2.0 \\ \text { Don't believe on group personal guarantee } & 2 & .7 \\ \text { loan } & & \\ \text { Not availability of loan at proper time } & 3 & 1.0 \\ \text { Any other problems } & 5 & 1.6 \\ \text { Total } & 300 & 100\end{array}$

Source: Survey data 2017-18.

Table 15: Contacts persons and institutions in case of financial problems.

\section{Person and Institutions}

Local agricultural credits officers

Governmental organization

\section{Number of Percent-} respondents age \%

Credits experts in banks

52

15.5

Non-governmental organizations

Friends and relatives

11.3

38

12.5

40

7.8

Total

144

47.7

300

Source: Survey data 2017-18.

Contacts persons and institutions in case of financial problems

Table 15 shows different contact persons and institutions which the respondents contact them 
in case of financial problems. Among them 15.5\% respondents contact with local agricultural credits officers, while $11.3 \%$ respondents deal with governmental organization and $12.5 \%$ respondents share with credits expert in banks, $7.8 \%$ contact with non-governmental organization while mostly respondents $47.7 \%$ contact with friends and relatives.

\section{Conclusions and Recommendations}

This study was conducted to examine the impact of microfinance on the socioeconomic status such as income, health, educational status, living standard, food diet pattern and transportation etc. and also to critically evaluate and analyze the problems faced by the borrowers to get the loans from the Khushhali Bank limited in District Dera Ismail Khan. Majorities of the respondents (72.2\%) replied that due to micro credits facility, their income increases. Due to increase in income, the respondents have got to use further money and to improve their health and get opportunity to better off health services. 82.2 (\%) of the respondents replied that microfinance has a positive impact on the children's educational status and due to microfinance the children of the farmers were moved from government to private schools. The children who were not going to school due to their monetary disaster, now they used to send their children to school. $85.1 \%$ of the respondents replied that there is significant enhancement in their family living standard due to microfinance facilities in the research area, and more than 50\% farmers replied that there is also significant improvement in their food diet pattern. And finally the overall study showed that microfinance has a positive and significant impact on the socioeconomic status of the farmers in the rural areas such as income, health status, educational status and living standard etc.

The other section of the study focused on the constraints experienced by the borrowers in getting the loans from the Khushhali bank limited and other microfinance institutions. The borrowers enumerated different problems such as high interest rate, no information about microfinance institutes, the complicated procedures of getting loans, not believing on microfinance, small loan amount and not availability of loans at proper time. And in case of financial problems, the respondents contact different persons and institutions such as local agricultural credits officers, with governmental and non-governmental organization and with friends and relatives. Finally, the study concluded that the overall socioeconomic status of the respondents had improved due to micro credit facility from the Khushhali Bank Limited and other governmental and nongovernmental micro financing institutions in the research area.

Government should pay special attention on the problems faced by the borrowers in microfinance institutions and try the possible way to solve it. The government should need to create awareness through the media among the peoples about the significance of microfinance throughout the country. The government should be directed to the microfinance institutions to provide the loans through easiest way, shortest possible and proper time. Government should provide interest free loans like Akhuwat Foundation. The government should need to introduce the microcredit's foundations in Pakistan to improve the socioeconomic status of the farmers. The government, State Bank of Pakistan and other Commercial banks of Pakistan needs to increase the average size of the microfinance loans, so that the farmers can get the maximum benefits out of it.

\section{Novelty Statement}

The issues experienced by the microfinance borrowers and also the Contact persons and institutions in case of financial problems of the borrowers was first time discussed in this research paper in the research area Dera Ismail Khan.

\section{Author's Contribution}

Muhammad Naveed Anjum designed the study, wrote the protocol and prepared the first draft of the manuscript from his M.Sc (Hons) thesis. Abdur Rehman did the data analysis, did model modification and rectification. Muhammad Niamatullah Khan Babar helped us in giving his useful suggestion about the model usage and data analysis. Raheel Saqib helped in typing of the manuscript and data editing. Muhammad Fayaz helped in collecting the review of literature and correction of the scholar thesis. Iqbal Javed also helped in collecting review of literature and correcting the grammatical mistake of the manuscript.

\section{Conflict of interest}

The authors have declared no conflict of interest. 
References

Adhikari, D.B. and J. Shrestha, 2013. Economic impact of microfinance in Nepal: A case study of the Manamaiju Village Development Committee, Kathmandu. Econ. J. Develop. Issues, 15(1): 36-49.

Ahmad, S., 2014. Socio-economic effects of microfinance on agricultural sector: An analysis of farmer's standard of life in Multan. Int. Rev. Manage. Bus. Res., 3(3): 1671-1682.

Aminu, S., and A. Samuel. 2015. Microfinance impact on agricultural production in developing countries. Int. J. Acad. Res. Reflection. 3(3): 2644.

Choudhury, H., A. Das and A. Rahman. 2017. The effectiveness of micro-credit programs focusing on household income, expenditure and savings. J. Compet., 9(2): 34-44. https:// doi.org/10.7441/joc.2017.02.03

Dipak, B., and S. Jayanti. 2013. Economic impact of microfinance in Nepal. Econ. J. Dev. Issues. 15(1): 36-49.

Ernest, A.G. and A.A. Kwame. 2014. A study of effects of microfinance credit on community farmers. New York J. Agric. Environ. Sci., 3(1): 67-88.

Faith K., and O. Kevin. 2017. Impact of access to credit facilities on youth economic development. Int. J. Res. Bus. Stud. Manage., 4(1): 24-36.

Hassan, H.Z., 2017. Impact of microfinance on socio-economic conditions of the borrowers. Eur. J. Multidis. Stud., 6(2): 239-248. https:// doi.org/10.26417/ejms.v6i2.p239-248

Haque, A., N. Anwar, F. Yasmin, A. Sarwar, Z. Ibrahim and A. Momen. 2011. Purchase intension of foreign products: A study on Bangladeshiconsumer perspective.Open J.1-12. https://doi.org/10.1177/2158244015592680

Iqbal, Z., S. Iqbal and M.A. Mushtaq. 2015. Impact of microfinance on poverty alleviation. Manage. Adm. Sci. Rev., 4(3): 487-503.

Meharul, N., M. Ismail and H. Altaf. 2016. Impact of microfinance on income of small farmers in district dadu. sindh. Sci. Inst. (Lahore). 28(3): 2763-2766.

Muhammad, I.Q. and A.M. Saleem. 2012. Socioeconomic characteristics of beneficiaries of rural credit (A case study of D.I. Khan
District, Khyber Pakhtunkhwa, Pakistan). Dev. Country Stud., 2(3): 53-66.

Muhammad, I.Q., A.M. Saleem, G.U. Khan and M.I. Ali. 2012. Role and impact relationship between microfinance and poor's access. Inst. Interdisciplin. Bus. Res., 3(10): 717-732.

Murad, A., 2017. The impact of microfinance institution in economic growth of a country. Int. J. Dev. Manage. Rev., 12(1): 1-17.

Nouman. M., M.F. Siddiqi, S.M. Asim and Z. Hussain. 2013. Impact of socio-economic characteristics of farmers on access to agricultural credit. Sarhad J. Agric., 29(3): 469476.

Oltiana, M., L. Edlira M. Filloreta and P. Erald. 2018. Evaluating the impact of microfinance at the individual level. J. Econ. Manage. Sci., 1(1): 143-155.

Perceval, N., Assogba, E. Senakpon, K. Haroll, N. Rosaine, Yegbemey and A. Jonas. 2017. Determinants of credit access by smallholder farmers. J. Dev. Agric. Econ., 9(8): 210-216.

Razaulhindaman, 2014. Impact of microcredit scheme on socio-economic status of farmers. Res. J. South Asian Stud., 29(1): 163-172.

Sivchou, T., P. Sokhak and M. Nara. 2011. Impacts of micro-credit on household economics. Int. J. Environ. Rural Dev., 2(1): 108-114.

Tahir, M., M. Farooq, H. Tooqir and Sattar. 2016. Impact of microfinance on income generation and living standard. Pak. Econ. Soc. Rev., 54(1): 73-80.

Urvashi, S., and R. Vinita. 2017. Impact of micro finance scheme on women. Res. J. Manage. Sci., 6(7): 11-16.

Viswanath, 2018. Microfinance and the decision to invest in children's education. Int. J. Financ. Stud., article. https://doi.org/10.3390/ ijfs6010016

Weerasinghe, I.M.S., and H.H. Dedun. 2017. Impact of micro finance on living standard with reference to microfinance holders in kurunegala district. Int. J. Bus. Mark., 2(7): 16-23.

Zahida, M., and A. Saira. 2006. Role of Punjab Rural Support Programme in increasing economic status and poverty alleviation efforts in rural Faisalabad. J. Agric. Soc. Sci., 2(2): 110111. 